Abstracta Iranica Abstracta Iranica

Revue bibliographique pour le domaine irano-aryen

Volume 28 | 2007

Comptes rendus des publications de 2005

\title{
« Regards sur le mouvement ethnique au Kurdistan iranien ». CEMOTI, n 38, 2004, pp. 185-204.
}

\section{Gilles Riaux}

\section{(2) OpenEdition}

1 Journals

\section{Édition électronique}

URL : http://journals.openedition.org/abstractairanica/20381

DOI : 10.4000/abstractairanica.20381

ISSN : 1961-960X

Éditeur :

CNRS (UMR 7528 Mondes iraniens et indiens), Éditions de l'IFRI

\section{Édition imprimée}

Date de publication : 15 mai 2007

ISSN : 0240-8910

Référence électronique

Gilles Riaux, « «Regards sur le mouvement ethnique au Kurdistan iranien ». CEMOTI, n³8, 2004, pp. 185-204. ", Abstracta Iranica [En ligne], Volume 28 | 2007, document 403, mis en ligne le 18 septembre 2007, consulté le 25 septembre 2020. URL : http://journals.openedition.org/abstractairanica/20381 ; DOI : https://doi.org/10.4000/abstractairanica.20381

Ce document a été généré automatiquement le 25 septembre 2020.

Tous droits réservés 


\title{
« Regards sur le mouvement ethnique au Kurdistan iranien ». CEMOTI, n 38, 2004, pp. 185-204.
}

\author{
Gilles Riaux
}

1 L'A. présente, succinctement et chronologiquement, le processus d'émergence de la conscience ethnique kurde en Iran à travers les principales révoltes qui opposèrent les Kurdes à l'État central durant le $\mathrm{XX}^{\mathrm{e}} \mathrm{s}$. : les révoltes d'Esmail Agha Simko dans les années 1920, la République de Mahâbâd de 1946 et les révoltes qui suivirent la Révolution islamique.

2 La deuxième partie de l'article, beaucoup plus convaincante, s'intéresse à la kurdicité et à son vécu, qui prennent de nouvelles formes dans l'Iran post-révolutionnaire. L'A. propose une typologie, qui introduit les facteurs religieux, sociaux, territoriaux et diglossiques des processus d'identification des populations kurdes. Elle introduit quatre types qui fonctionnent selon la volonté ou le refus de négocier entre identité ethnique et nationale : pour la volonté, le militantisme dans l'affirmation de l'identité locale ou le multiculturalisme dans l'intégration non discriminante; pour le refus, le traditionalisme ethnique dans la continuité ou l'assimilation à l'identité iranienne, confondue avec la persanité.

\section{INDEX}

Thèmes : 12.1. Iran 
AUTEURS

GILLES RIAUX

Paris 